\title{
雅庫特語方言的研 究
}

\section{E. 鳥市里雅托瓦}

蘇聯科學院雅庫特分院語言交學歷史研究所 會同蘇聯科學院語言研究所進行研究雅庫特浯的 方言已有兩年。第了造㑉目的, 蘇聯科學院雅庫特 分院棕合考察葍的方言調杰隆工作了兩季, 研究 雅形特語言的地方特點。1950年夏, 這個工作在烏 斯㓶・阿爾丹和阿穆金地區進行・1951年在上維 留是和維留易地方進行。

雅庫特自治蘇維埃社會主義共和國是均於俄 羅斯聯邦的。它的領域很大一一差不多有四百茧 本方公里。主要的居民是雅庫特人（約有二十五. 㒖人), 說一種乫频語族的語言。

在偉大的十月革命以前, 儘管雅庫特有無䇱

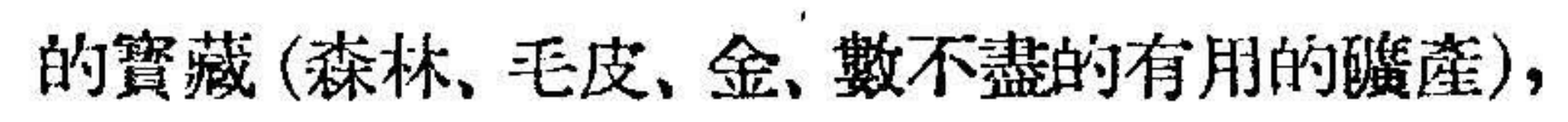
它還是一倜非常落後的地方。主要居民從事遊牧 (駡、牛), 其組織是很原始的。工商業完全沒有。気 候嚴害和交通閉塞加重了雅庫特人民生活條件的

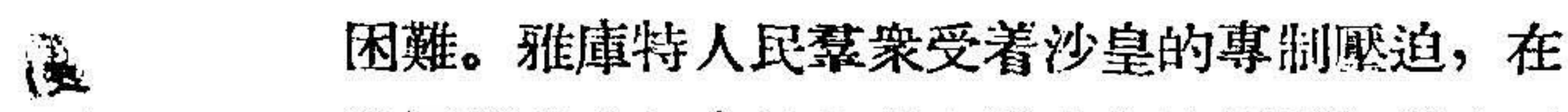

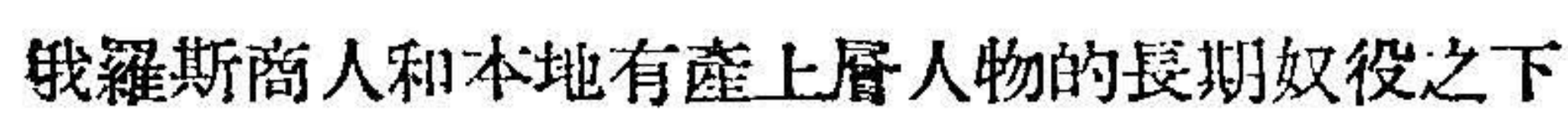
䬺日。文化水平可以拿下面的事情表示妆束: 一 般全不識字(裁字的佔總人口數的 $0.7 \%$ ); 臀㴖敉 哭區别地統治着一切; 生活不講衛生, 那種生活曾 引起多種傳染病和流行病。

雅㡷特人民在革命前所有的唯一的文學斯富 就是他們口頭流傳的人民創作。這些創作中包含 訢多民謡、故事、詩歌、野史、傳說、哜語、格言和謎 語泍同這些作品的非常發展的口頭文學語言。在 汥有公民權又受痛苦的雅庫特人那種非常困難的 生活焂件的環境中, 居然有這種剘富, 這是裳使研 1 究的人吃第的。但是, 這正好表明雅庫特人的偉大 創作能力。

起立了蘇維埃政權的雅庫特人的生活根本改 柰了。1922年內戰結束以後,就建立了雅症特自治 碂維埃社會主羲共和國。在新的基礎上組織起共

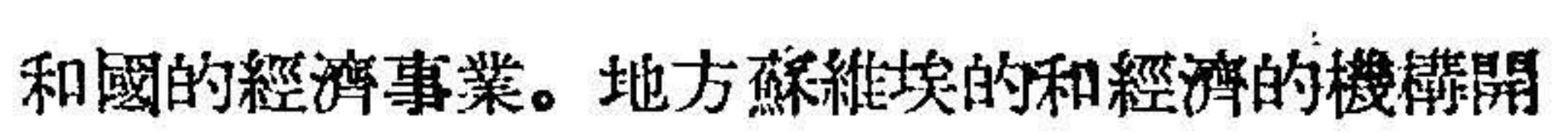
始注意䩗足居民的日常霞姴和要求。探金工業創

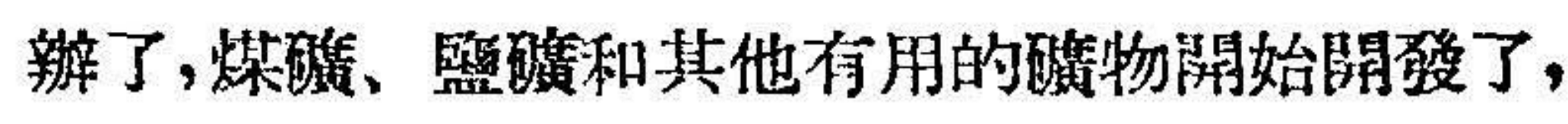
渾輸事業發㞗了, 發電站出現了。地方的主要居民 組成集體農荘, 在集體農菲中共和國的全部㖘業 得到新方向，新規模。耕作的發展引起汽車、拖拉 機站的任現，大有助於得到高度的收檴。

雅庫特自治蕉維埃䇛會主義共和國在文化建 設部門中的成功特大。到共和國建國25周年的時 候它已經變成全國人民普遍識字的國家了。就在 那一年, 雅涷特自治蘇維埃形會主義共和國中開 設了一倍蘇独科學院科學研究基地, 不久久改篇 蘇聯科學院分院, 領導共和國的全部科學研究工 作。雅庫特人民能够以這樣空前的速度提高文化, 是因篇一開始就根據我們黨的賢明的列鼻斯大林 地族政策，使兒童學校的教育和成年人挖除文盲 的教育都用當地居自自己的語言進行。這就保登

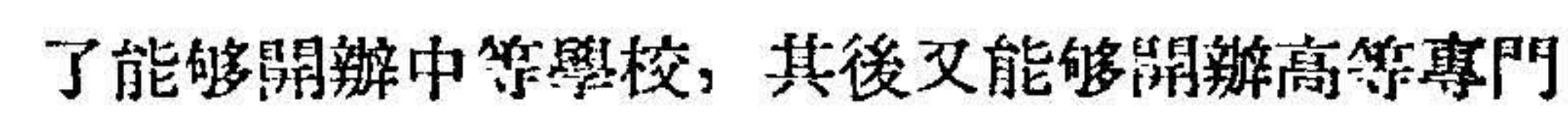

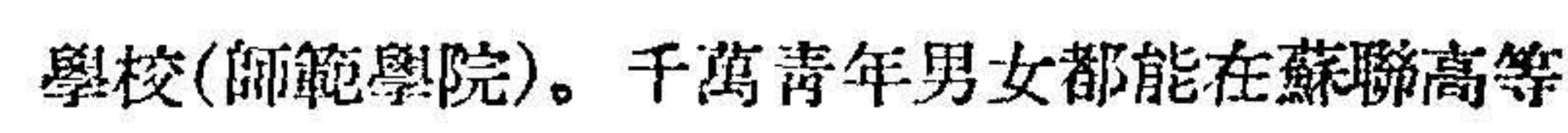
學校受高等教育。文化部門和人民經沾部門的多

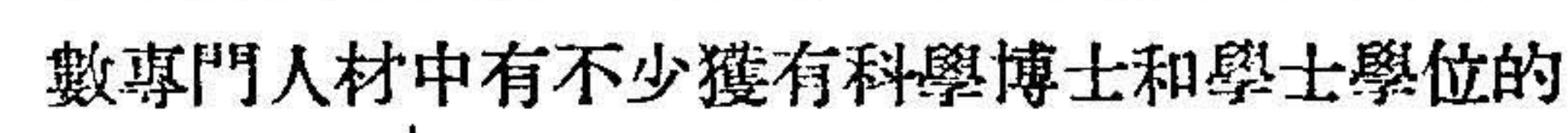
工作人員。

居民自己的語言。也就是現在所說的雅庫特 語, 在創造雅庫特人民文化的事業中起了非常重 要的作用, 這文化按形式是民族的, 按內容是社會 主義的。出版報祇、雜誌、書籍, 演戯, 教書, 在集體

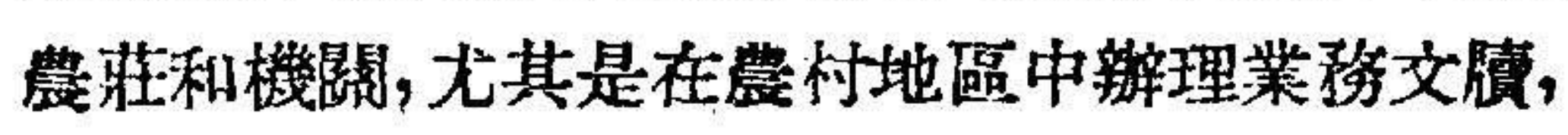
都是用的這種語言。因此, 在共和國中非常重視學 習雅庫特語,特别重視學習新造的文字。绍了造個 目的, 1935年在雅庫特自治蕉維块社會主哦共和 國人民政治委員會下就組織了語言文化研究所, 這侗機構主持研究文學語言，出版数科書和衙語 詞典, 研究正字法和標點等號。後來改組第語言文 


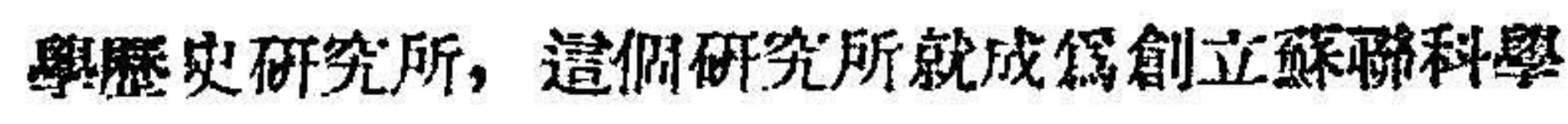
院科學研究基地的基礎。

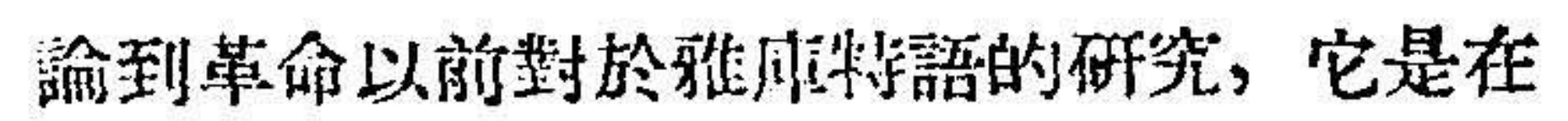

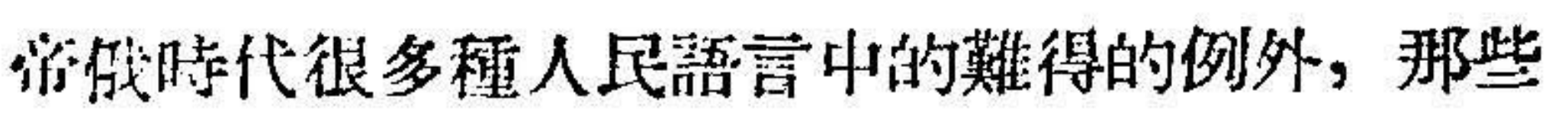

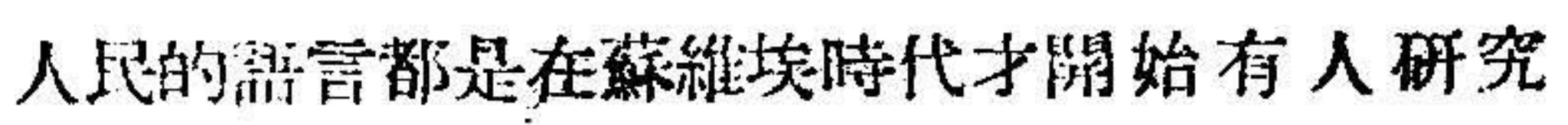
的, 而雅同特特新則是就有人研究了。今年距伯德特

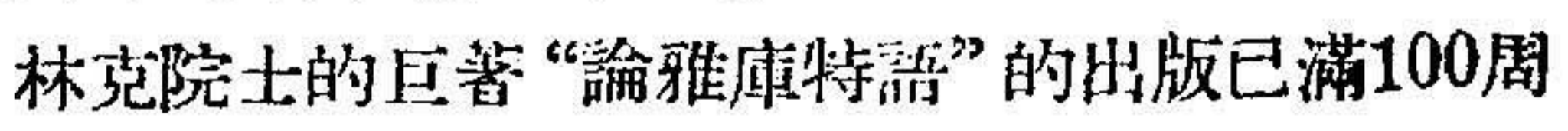

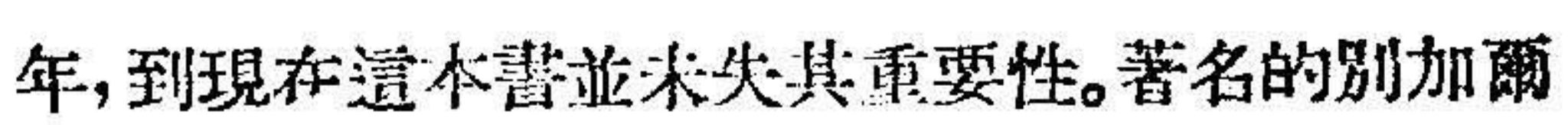
斯克的“雅麻特管字典”自1907-1930年分册出 掘; 這部書是研究雅庫特的語言學家、歴史學家、 人種學家、民俗學家的案嘼必借的參考書。造些書 和其他有關雅庫特語富作品的出版，一方面要歸

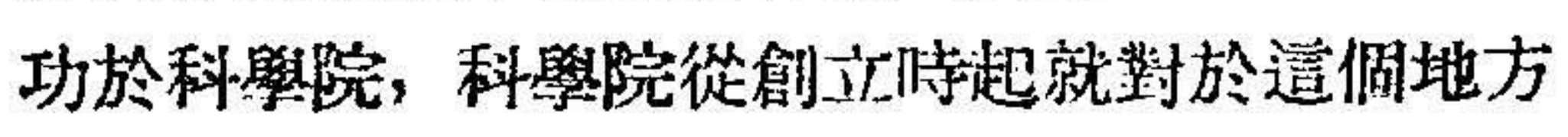
關心，派遗了考察䊅到這做地方落集了不少的雅 庫特語言的材料; 在另一方面要感謝被沙皇專制

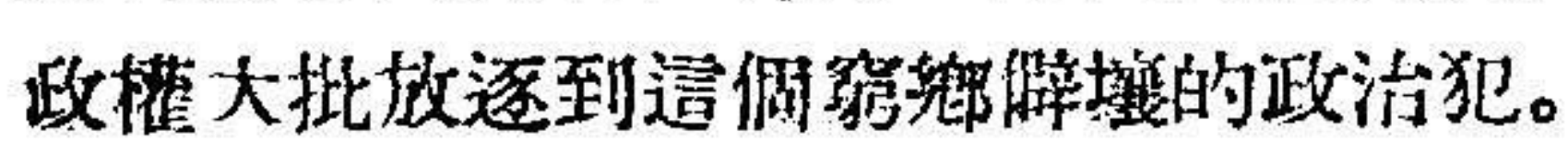

在舊的著作中特别在政治犯别加醉斯克、雅 斯特列棃斯克、伊鄂諾夫、胡賈昆的著作中都菟集 有很多的雅瑓特浯的方言材料。但並来說方言的 分枝很大，甚至於相信在雅鿰特語中浑有極不相 同的方萿。因此, 在最初陵年, 蘇維埃政權推行以 本地活第基礎的新文字時, 問題解決得非常简單。 到琭除成年居民的文宣時,教他們認識了字母(美) 不多同時已經把書舁出來了), 就急躁地教他們書 舄的技術, 蓝且說: “你怎縻說就怎㦄舄吧!”過了 不久發現他們有許多地方鼠的不同，因第他們說

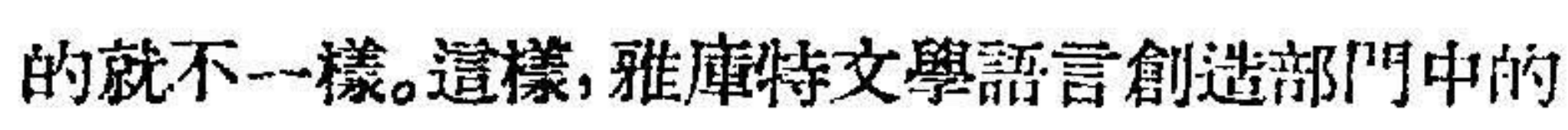

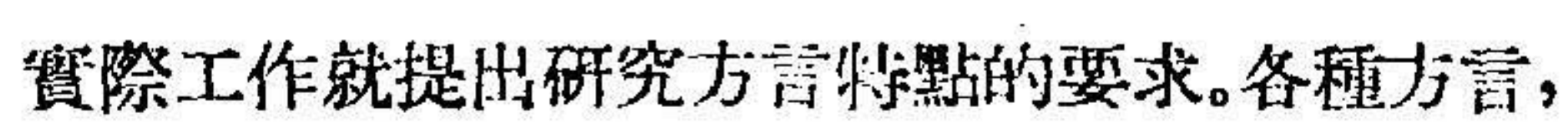
由於文字是探用標吾原則的, 若按㓣造的正字法

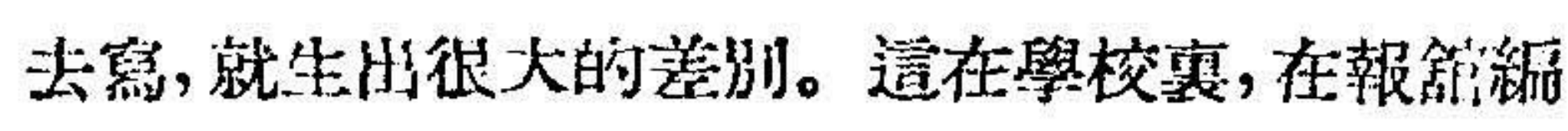
軒部裹, 作家與作家間, 引起了很多的等論。但是 那時還沒有調查方言分枝現象的專家。

在雅庫特自治蘇維流社會主義共和国以一地 語言筑基磼創造文字的最初幾年, 也跟在我國的 其他的共和國一樣, 在共和國本身，一切語言工作 都集中在造一點上。由於缺之專家,所以就把教員 們也吸收爽案加工作。因媱當時必須火速給學校 和琭宣站供應教科書, 還要寫文章和文藝作品, 還 要進行科學研究。

一直到從雅庫特人中間潐储好了語言學專家 的時候, 才䅈手搞方言研究工作。

精通雅庫特語的雅埂特第一流的詩人庫拉克

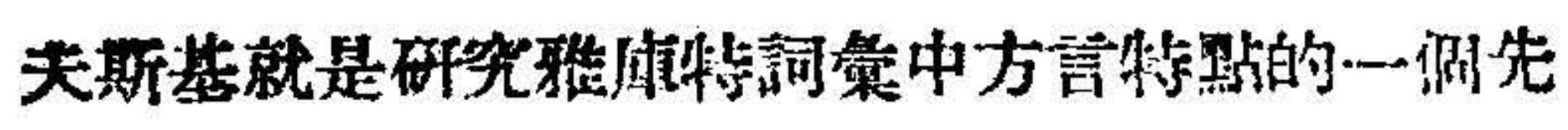

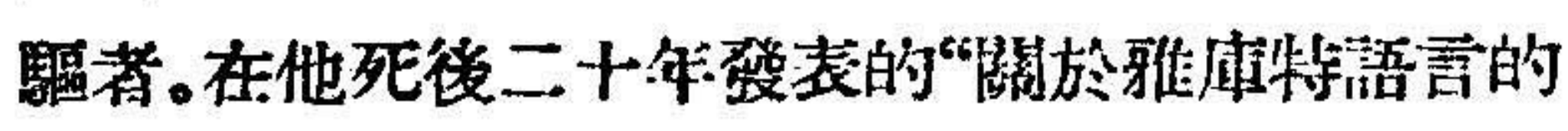
諭文和材料” (雅庫次克, 1946) 中包含760倜宇可 以通用於雅庫特自治葆維埃䇛會主義共和國中各 湖不同地湂。

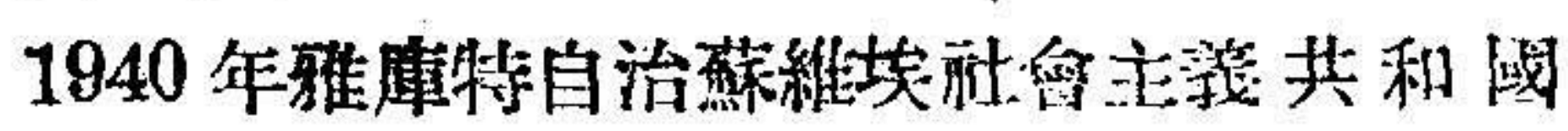
人民政治委員會語言文化研究所内柴莫達聑主編 印行了一連專門的方容學問題小胜, 目的在通過 學校教員蒐集方言材料。就在那一年完成了兩部

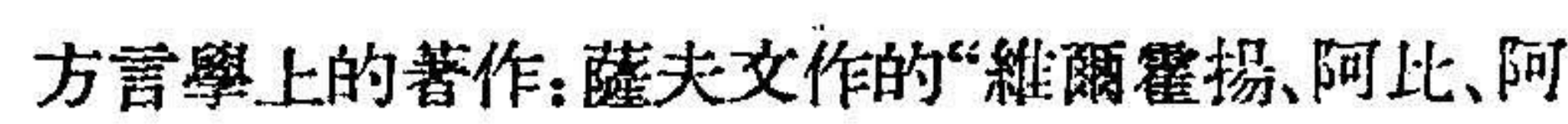

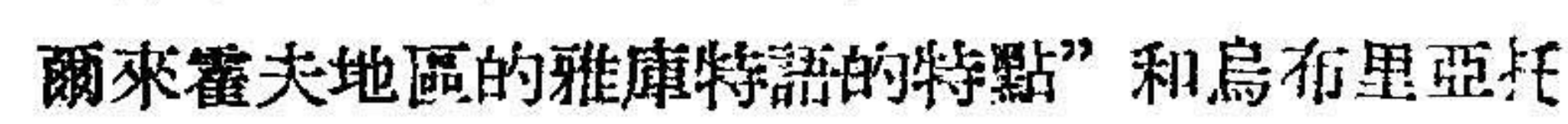
瓦作的“部瑞里道爾幹势言”。

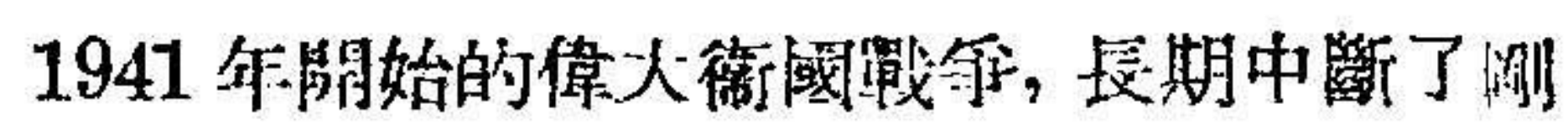

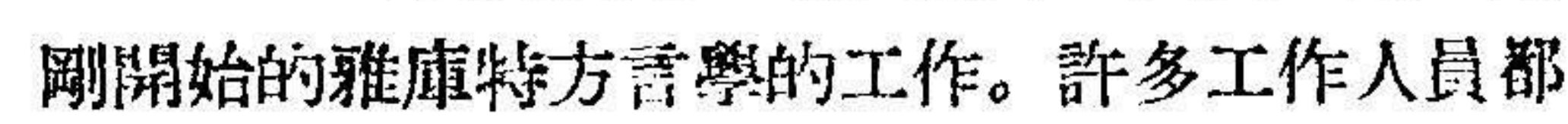

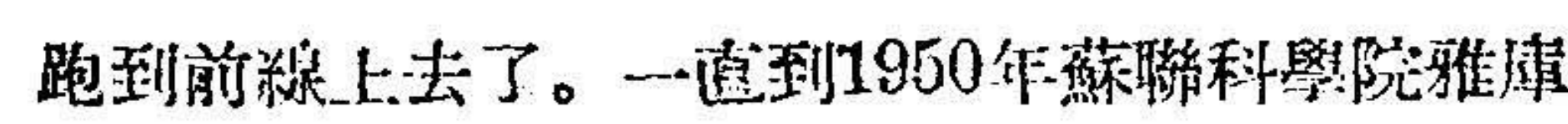

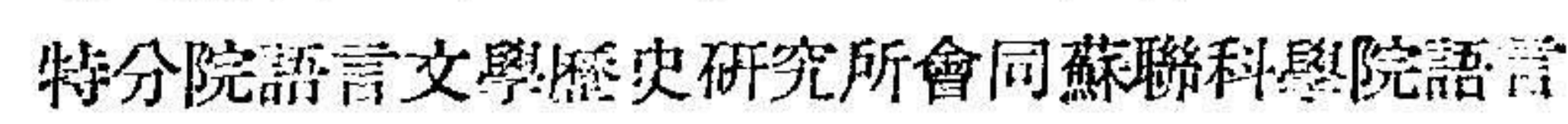
研究所才能着手有系統堣筧集雅庫特語方言材

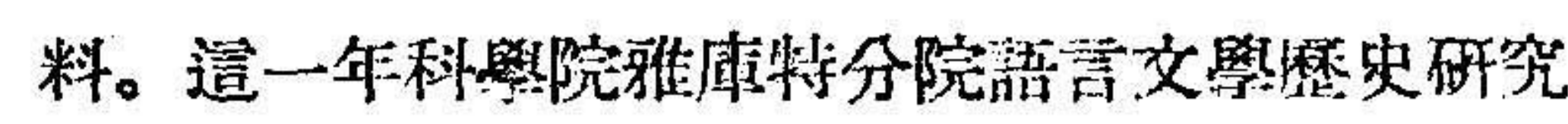
所棕合搭察圈的方言調查榢社驗出發到雅庫特自

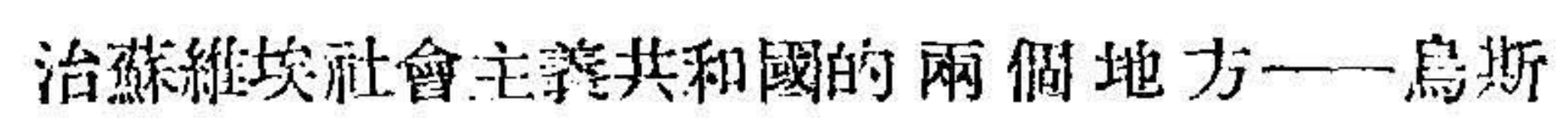
蒂・阿雨丹和菏穆金。調查榢的五人組成。

在雅麻特自治蘇維埃社會主義共利國的中坐 地區, 現在有很好的道路。因此, 方言調查隊能坐 汽車走一千五百解公里。在方言調查除的前面揭 着雨倜任弱: 真集有特徽的方言材料和探測雅庫 特文學語部對地方人民語的影響程度。篇回答頭

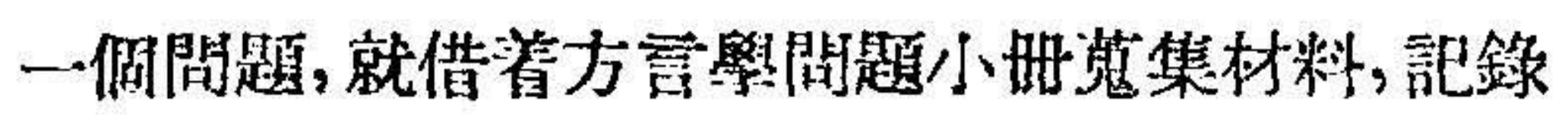
整段東西（大牛不是民俗學的，因第雅庫特民俗學

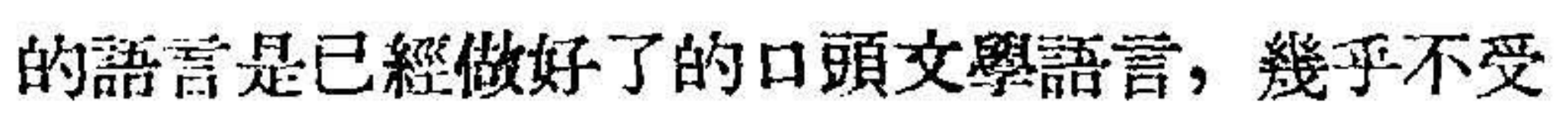
語㝘的地方特點的拘束, 所以不適於觀察方霄)。 䉆回答第二倜間題, 就研究了那些記銑的整段材 料, 在地方居民的口語上進行觀察, 特别研究了集

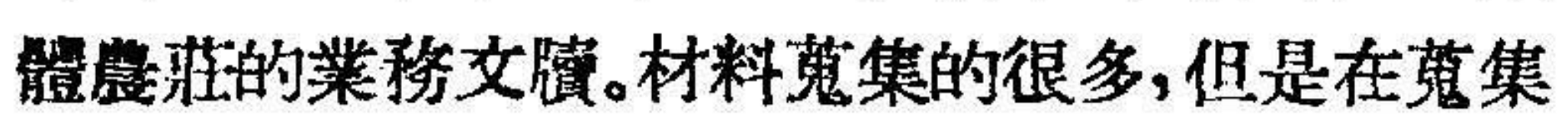
材料過程中能够得仙的結論，好像在第二個閣題

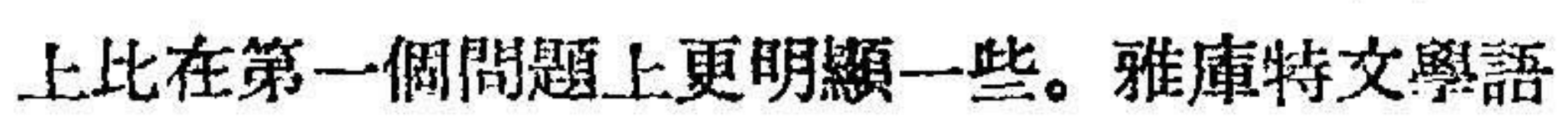
宗在當地居民哣言上的影響可以清清楚楚地看出 來, 在集體農莊的業務文領㧼本上表現的尤其清 楚。集體豊菲會議記錄和村蕉維埃的會議記錄上 无滿了政治名詞和專門名詞, 跟省辦報紙 “炏?

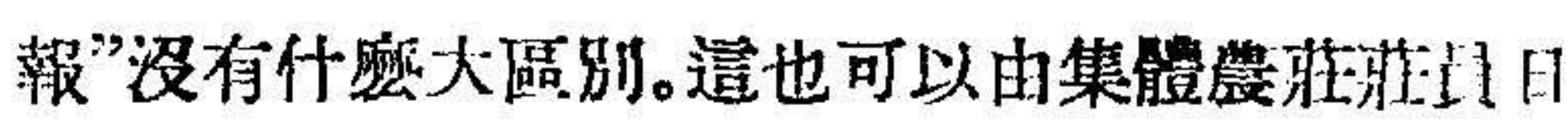
常說的話和記錄的文件上看得出來。令人感興趣

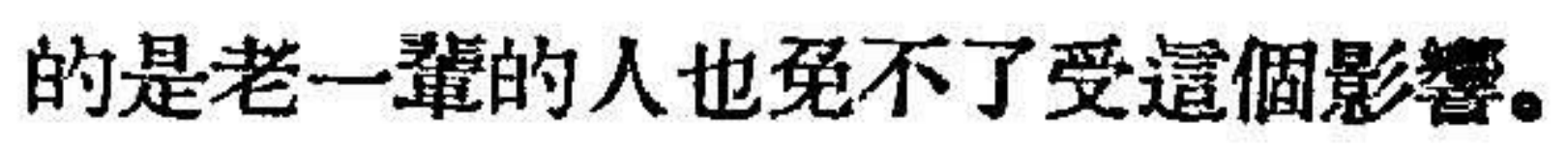


論到地方語的方言上的差別，乍一香來，好像 只在洞率方面。語昔上的特點似乎不稳定, 所以是 不斨重要的(話幹中的元音隨意同化)。研究所裹 精研材料以後, 才把地方方言的特點觀察的清楚 些, 不過結諭還是涗在當洔已經調查的地區裹朱 必談得_上雅库特語有特殊的方容。一还到1951年 開始另外一些地區的工作時, 所有我們讨觀察才 得到新的僻糮。

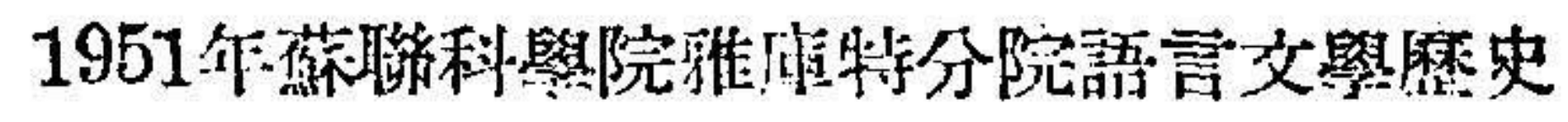

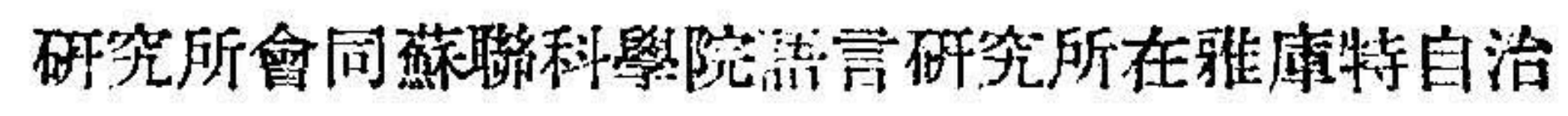
蘇維埃前會主義共和或維留易和上維留易地區繼 續左言上的工作。

維留易和、上維留易敨共和國的首傅有 650 -

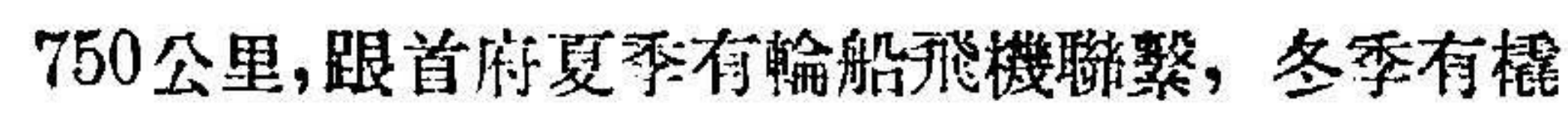

\&道聯熬。北部的村狧離地區的中央有200-280 公里, 在夏季我不能經過那些不可通行的沿灌 地䔩到這些村莊去。尼基佛洛夫在上維留易地方 工作時曾到達地區的北部。地區北部侍倜叫做熙

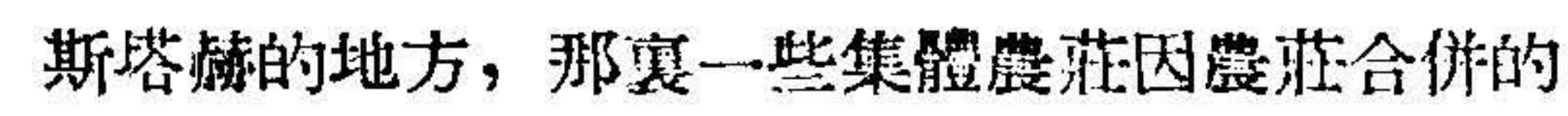
關係薽到地區的中部, 於是在維蛁易工作的人員 就利用逢假機會到了地區的中部, 因第這是主要 居民集中的地方。調枯隊又遇到從地湂北部另一

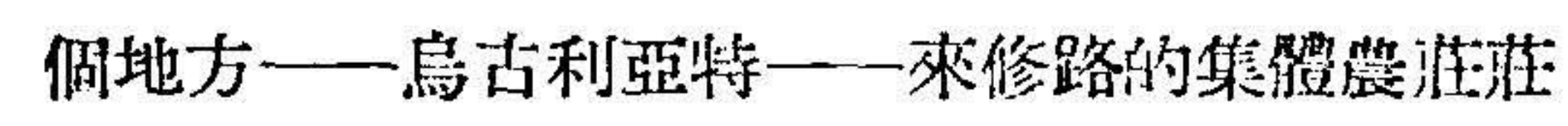
員。這樣, 就接解到了所有的最重姴的居民集疄。 在两做地區的行程大約有 700 公里,一部分是㚡点 走的,一部分是徒步走的。

各地的居民對於方言调查舫的工作都很感興

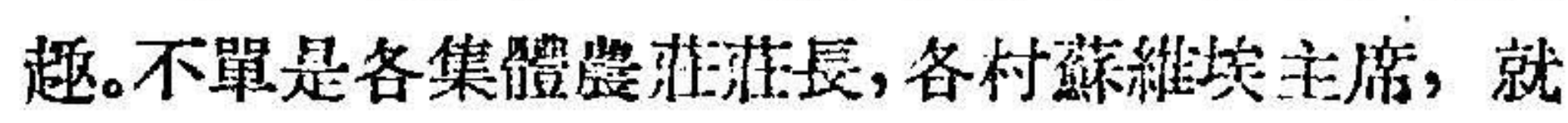

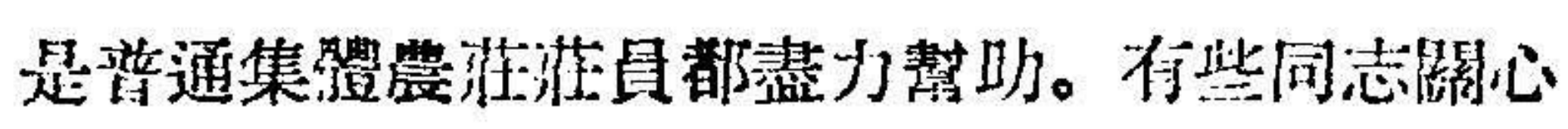

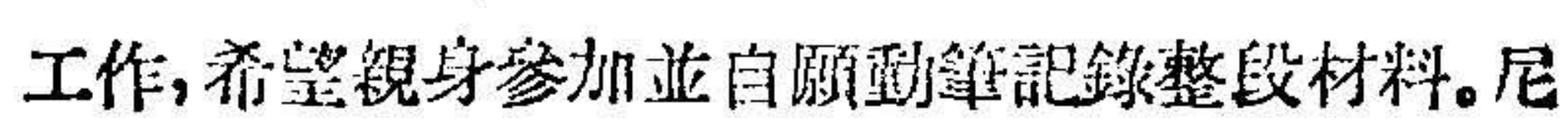

古拉耶头在周楚伊付口述“故事”和“迎夏歌”网篇 教他的徒弟篗錄下來。别爾金村 “十七倜青作團

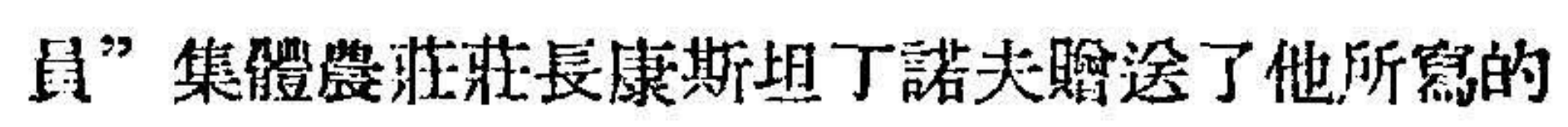

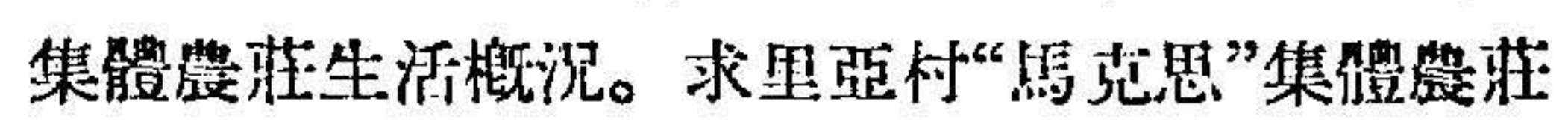
莊員吉利利娜訅錄了她自己的愛情故事 “美尼 克・亞力山大拉”。烏古利亞特村“列窂”集體表菲 莊員列别得金記錄了快板和雅庫特人民故事。所 有這些記錄在最後研究材料洔都很有用處。我們 第紀念斯大林的㥳史性著作發表一周年，組織了

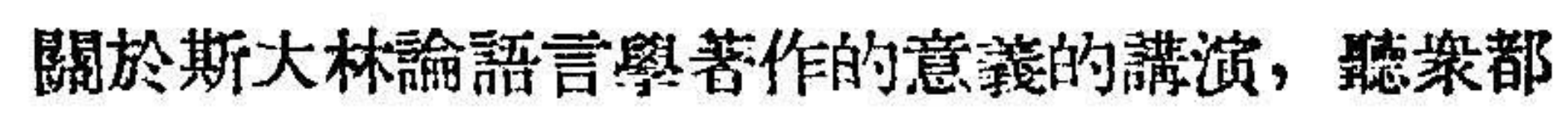
以極大的興趣倾聽。

- 材料是用到錄整段東酒和回答問題的方法䈭 集的。整時能作出來的初步結諭是: 維溜易地方的 語言有它的特性，表朋這偑地方的語言跟文繁雅 庫特語不同，跟阿礐金人和烏斯营・阿爾丹人的 語言更不同。此外，上面說過的那些不關重要的事

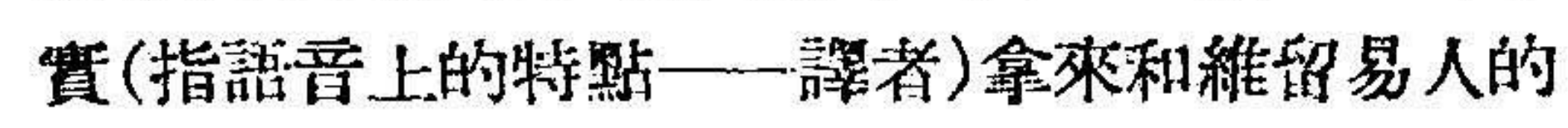
話來對照一下, 就有了地方語的(或者甚至於可以

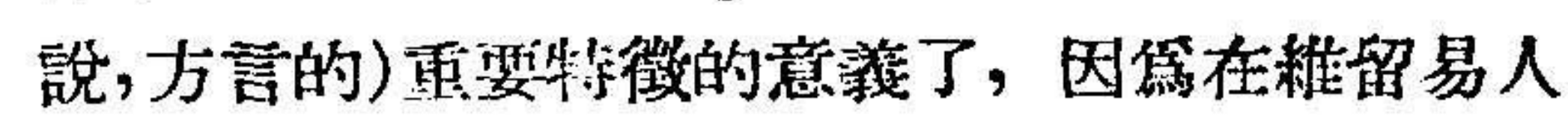
的話中汥何那些事筫。

還有一件附趣的事: 跟文學雅廟特語不同的

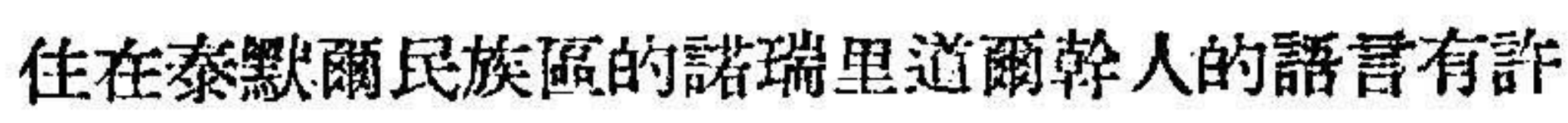
多特性和維留易人的語言相合。

現在作總結袈早一些，但有一件事是浔有疑 問的，就是對雅瑓特地方上活作進一步的研究可 以把這種有䞚而有特色的突㴊語族語言的主要方 言都找出來, 详且, 可能侍辦洗僻決至今還是一佔 謎的它的起源閏邀。

\section{〔王輔世澤】}

